\title{
Physical violence among elderly: analysis of admissions to an emergency department
}

\author{
Yasemin Kılıç Öztürk, M.D., ${ }^{1}$ Erhan Düzenli, M.D., ${ }^{2}$ Cem Karaali, M.D., ${ }^{3}$ Faruk Öztürk, M.D..
}

\begin{abstract}
${ }^{1}$ Department of Family Medicine, Tepecik Training and Research Hospital, İmir-Turkey
${ }^{2}$ Department of Emergency Medicine, Medicana Konya Hospital, Konya-Turkey

${ }^{3}$ Department of General Surgery, Tepecik Training and Research Hospital, Izmir-Turkey

${ }^{4}$ Department of Emergency, Menemen State Hospital, İzmir-Turkey
\end{abstract}

\section{ABSTRACT}

BACKGROUND: Physical violence is defined as deliberate use of physical force likely to result in trauma, bodily injury, pain, or impairment. Present study is pioneering effort to evaluate mechanisms and sociodemographic features of physical violence targeting the elderly in Turkey and to investigate preventive measures.

METHODS: Database records and forensic reports were analyzed in this retrospective study of 54 elderly patients with trauma as result of physical violence who were admitted to emergency department of Şanlıurfa Training and Research Hospital between January 2012 and July 2013.

RESULTS: Of the 54 patients evaluated, 50 (92.4\%) were male. History of experiencing previous violence was described by $55.6 \%$ $(n=30)$ of the patients. Instances of repeat violence and firearm injuries most often occurred in the home $(p=0.006, p=0.007)$. Need for surgical treatment was also greater among cases that occurred in the home $(p=0.016)$.

CONCLUSION: Firearm injury, recurrent violence, and surgical treatment rates were higher among cases that occurred in the home. Urgent preventive measures are especially needed for the elderly who have already been victims of physical violence.

Keywords: Geriatric; injury; neglect; preventive health care; trauma.

\section{INTRODUCTION}

Elder exploitation is a worldwide problem of human rights and public health. According to data of World Health Organisation, European population aged 65 years and over may reach $25 \%$ by 2050 . Currently at least $2.7 \%$ of older adults worldwide experience physical violence, and that percentage is expected to increase annually. ${ }^{[1]}$ In our country, elder population is estimated to reach 12 million by $2050 .{ }^{[2]}$ It has also been reported that $\mathrm{I}$ in 10 individuals over 60 years old faces some form of abuse based on statistics from different countries. ${ }^{[3,4]}$

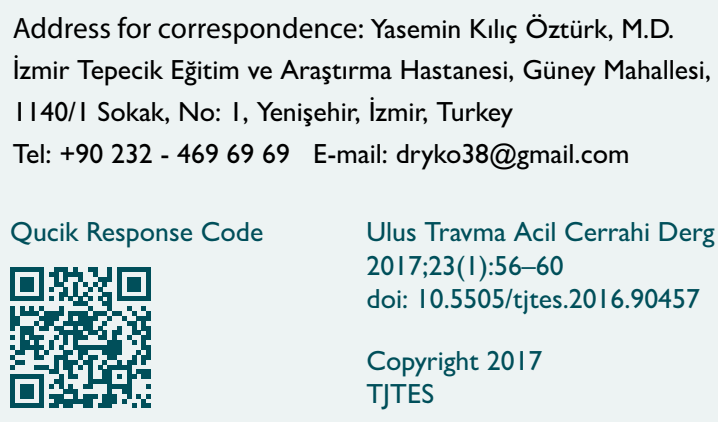

According to the literature, abuse lowers life expectation for elderly victim. Abuse concept includes 5 types: physical, psychological, and sexual abuse, neglect, and financial exploitation. ${ }^{[5,6]}$ Physical violence may result in bodily injury, pain, and function loss in the victim. ${ }^{[7]}$ What makes the problem more profound is that those inflicting physical violence are most often relatives of the victim. ${ }^{[8-10]}$ In such cases, the victim often keeps the violence a secret and refuses to talk about it, which makes resolving the problem more difficult, and may eventually lead to the death of the victim.

In order to avoid elder abuse and exploitation, it is stressed that an older person be removed from an abusive situation during conflict, that care and support be provided, and furthermore, that medical professionals often have the obligation to report instances of abuse. ${ }^{[1]}$

Literature review revealed that $19 \%$ of admissions to emergency department are for diseases related to old age. ${ }^{[2]}$ Another study indicated that $3.8 \%$ of geriatric patient admissions to emergency department were due to trauma. ${ }^{[3]}$ Unfortunately, we have limited epidemiological data about unknown and unidentified trauma, and thoroughly investi- 
gated data collected from detailed studies occupies a limited place in the literature.

In the present study, which is a first in our country, the aim was to investigate precautions to prevent elder abuse by evaluating the physical assault mechanisms and sociodemographic features of geriatric patients admitted to emergency department due to physical violence/assault.

\section{MATERIALS AND METHODS}

In this retrospective, sectional study, hospital database and juridical reports of patients 65 years of age and older who were admitted between January I, 20I 2 and July I, 2013 to emergency department of Sanlıurfa Mehmet Akif Inan Training and Research Hospital with complaint of physical assault or abuse were reviewed.

Ethical approval was granted by the ethics committee of Tepecik Training and Research Hospital and permission for the study was given by the management of Şanlıurfa Mehmet Akif İnan Training and Research Hospital. Data including sociodemographic features (age/sex) of the individuals, means of admission (private vehicle/ambulance), trauma mechanism, injured body area, perpetrator identified by the patient, diagnosis, past history of violence, severity of trauma, treatment result, and place where injury took place, were collected and entered into spreadsheet. Injuries to the abdomen or thoracic organs caused by blunt or sharp objects were identified as internal organ injury. The following result criteria were applied to separate patients into 2 groups: patients discharged from emergency after simple treatment (intervention) and patients who had to be hospitalized due to serious injuries. Descriptive statistics, chi-square and Fisher's exact test were used for the statistical analysis of the data. $\mathrm{P}<0.05$ was considered statistically significant.

\section{RESULTS}

Of 54 elder patients evaluated due to physical violence, 50 (92.4\%) were male, and 4 (7\%) were female. Total of $48.2 \%$ $(n=26)$ patients were between 65 and 69 years of age, $37 \%$ $(n=20)$ were between 70 and 74 years of age, and $14.8 \%(n=8)$ were between 75 and 79 years of age. Most, 88.8\% $(n=48)$, were admitted to emergency department in the afternoon or evening, between 12:00 pm and 8:00 pm. Elders brought to emergency department by private vehicle represented $70.4 \%$ $(n=38)$ of study group. Most frequent sites of injury were face/head neck (38.9\%; $n=21)$, thoracic region $(33.8 \% ; n=18)$, and abdominal area $(14.8 \% ; n=8)$. When 8 cases of intra-abdominal injuries were studied, isolated organ injury of liver $(n=2)$, intestine $(n=2)$, and splenic injury $(n=1)$ were found, and 3 cases were multi-organ injury.

In 26 cases (48.1\%), there was internal organ injury, and in II cases $(20.4 \%)$ there were skin lacerations. According to pa-
Table I. Main features of the cases

\begin{tabular}{|c|c|c|}
\hline & $\mathbf{n}$ & $\%$ \\
\hline \multicolumn{3}{|l|}{ Injured body part } \\
\hline Thorax & 18 & 33.3 \\
\hline Head or neck & 12 & 22.2 \\
\hline Face & 9 & 16.7 \\
\hline Abdomen & 8 & 14.8 \\
\hline Upper extremities & 6 & II.I \\
\hline Lower extremities & 1 & 1.9 \\
\hline \multicolumn{3}{|l|}{ Diagnosis } \\
\hline Internal organ injuries & 26 & 48.1 \\
\hline Skin laceration & II & 20.4 \\
\hline Soft tissue injury & 6 & II.I \\
\hline Upper extremity fracture & 6 & II.I \\
\hline Isolated head trauma & 3 & 5.6 \\
\hline Maxillofacial injury & 1 & 1.9 \\
\hline Lower extremity fracture & I & 1.9 \\
\hline \multicolumn{3}{|l|}{ Treatment applied } \\
\hline Major surgery & 29 & 53.7 \\
\hline Primary suture & 11 & 20.4 \\
\hline Pharmaceutical treatment & 8 & 14.8 \\
\hline Plaster splint & 6 & II.I \\
\hline \multicolumn{3}{|l|}{ Wounding implement } \\
\hline Stick or similiar object & 26 & 48.1 \\
\hline Firearm & 25 & 46.3 \\
\hline Any limb (hand. foot) & 3 & 5.6 \\
\hline
\end{tabular}

tient's statement, $63 \%(n=34)$ of the injuries happened outside the home, while $37 \%(n=20)$ happened in the home. Member of immediate family was identified by patients as perpetrator of physical assault in $14(25.9 \%)$ cases, other relative in 33 $(61.1 \%)$ cases, and a stranger in 7 (13\%) cases. Past history of experiencing violence was described by $55.6 \%(n=30)$ of cases (Tablel). There was no statistically significant relationship between history of violence and age, gender, hospitalization requirement, or type of perpetrator described by the victim. History of repeated violence was observed more often when violence took place at home $(p=0.006)$. Number of injuries due to firearm was significantly higher in cases where violent incident took place at home compared with those that took place outside the home $(p=0.007)$ (Table2). Rate of need for surgical treatment was also higher in cases where violence occurred at home $(p=0.016)$ (Table3). No early mortality occurred during the investigation, treatment, and observation of cases in emergency department.

\section{DISCUSSION}

In all age groups, trauma is still a leading cause of death. ${ }^{[14,15]}$ 
Table 2. Reationship between location of crime, mechanism, and result of violence

\begin{tabular}{|c|c|c|c|c|c|c|c|}
\hline & & \multicolumn{2}{|c|}{ Home } & \multicolumn{2}{|c|}{ Outside } & \multirow{2}{*}{$\frac{\text { Total }}{\mathbf{n}}$} & \multirow[t]{2}{*}{$\mathbf{p}$} \\
\hline & & $\mathbf{n}$ & $\%$ & $\mathbf{n}$ & $\%$ & & \\
\hline \multirow[t]{2}{*}{ Mechanism } & Stick/Hand/Foot & 6 & 30 & 23 & 67.6 & 29 & 0.007 \\
\hline & Firearm & 14 & 70 & II & 32.4 & 25 & \\
\hline \multirow[t]{2}{*}{ Surgical treatment } & No & 5 & 25 & 20 & 58.8 & 25 & 0.016 \\
\hline & Yes & 15 & 75 & 14 & 41.2 & 29 & \\
\hline Total & & 20 & 100 & 34 & 100 & 54 & \\
\hline
\end{tabular}

Table 3. Factors related to recurrence of violence

\begin{tabular}{|c|c|c|c|c|c|c|c|}
\hline & & \multicolumn{2}{|c|}{ Recurrent } & \multicolumn{2}{|c|}{ First instance } & \multirow{2}{*}{$\begin{array}{c}\text { Total } \\
\mathbf{n}\end{array}$} & \multirow[t]{2}{*}{$\mathbf{p}$} \\
\hline & & $\mathbf{n}$ & $\%$ & $\mathbf{n}$ & $\%$ & & \\
\hline \multirow[t]{3}{*}{ Perpetrator } & Immediate family member & 10 & 71.4 & 4 & 28.6 & 14 & \\
\hline & Other relative & 15 & 45.5 & 18 & 54.4 & 33 & 0.173 \\
\hline & Stranger & 5 & 71.4 & 2 & 28.6 & 7 & \\
\hline \multirow[t]{2}{*}{ Crime scene } & Home & 16 & 80 & 4 & 20 & 20 & 0.006 \\
\hline & Outside & 14 & 41.2 & 20 & 58.8 & 34 & \\
\hline \multirow[t]{2}{*}{ Result } & Discharge & 7 & 41.2 & 10 & 58.8 & 17 & 0.149 \\
\hline & Hospitalization & 23 & 62.2 & 14 & 37.8 & 37 & \\
\hline
\end{tabular}

According to 2015 report using data obtained from National Trauma Data Bank in the USA, $29.7 \%$ of trauma cases were observed in patients aged 65 years and over. ${ }^{[16]}$ From medicosocial point of view, among geriatric age groups, which are considered to be highly vulnerable, trauma as result of physical violence (physical assault) is second to traffic accidents. ${ }^{[17,18]}$

Tanrıkulu et al. reported on importance of falls among cases of geriatric trauma, and it was noted that cases of geriatric violence were $1 \%$ of total in their study. ${ }^{[19]}$ This low percentage may be related to regional and cultural differences in 54 cases from $11 / 2$ year period included in present study, or may also be related to fact that all of cases of geriatric violence may not have been identified as such. Articles available in the literature indicate that $I$ in 10 elders faces abuse but only $I$ in 5 or fewer reports the mistreatment. ${ }^{[20]}$ Even minor injuries may increase mortality risk among elderly patients. ${ }^{[21]}$ In unreported cases of violence, patients may recover with simple treatments performed at home or may be too disabled to go to hospital or police by themselves. In the literature, while evaluating data concerning frequency of geriatric assault, it must be kept in mind that the matter is still almost taboo. ${ }^{[1,22,23]}$ Social mores surrounding family and privacy contribute to low rate of reported assault cases. Furthermore, doctors may not suspect assault in case of fall or other injury seen in elder patient.
Santos et al. reported negative correlation between abuse and aging, with exception of financial abuse. However, though prevalence declined with age, high incidence of injury to head and neck was observed. ${ }^{[8]}$ Martins et al. noted primacy of financial abuse before 75 years of age, and physical or emotional abuse and neglect after 75. ${ }^{[22]}$ Though no significance was found between physical violence and age or gender in this study, larger series are needed to investigate these relationships.

In the literature, most common form of geriatric trauma is traffic accident, most injured areas are head/neck and extremities, and most frequent diagnosis is soft tissue trauma. ${ }^{[17,19]}$ In our study of geriatric trauma, primarily face, head, and neck injuries were seen, followed by thoracic and abdominal areas. Use of wooden sticks, sharp or penetrating tools, and firearms often cause such injuries in assault cases, and may be related to large number of patients who required surgical treatment after internal organ injuries.

Need for hospitalization of the patients in this group was determined to be $68.5 \%$. This is higher rate than reported by Kandiş et al., 17\%, and higher than that of Tanrıkulu et al., at $12.4 \% .{ }^{[17,19]}$ This difference may be due to regional and cultural reasons or severity of trauma and necessity for surgical treatment. 
Another important issue is means of arrival to emergency department. In the study of Kaldırım et al., it was reported that $37.45 \%$ of patients reached emergency department via ambulance, and $16.1 \%$ of these were trauma cases. ${ }^{[12]}$ Another study determined that $70.5 \%$ of geriatric patients arrived at emergency department by private car. ${ }^{[17]}$ Present study results indicated $70.4 \%$ of elderly emergency department admissions arrived by private vehicle.

In this study, $92.4 \%$ of the geriatric violence cases were male. This data is similar to results of Tanrıkulu et al., but differs from other studies in the literature. ${ }^{[8,17,19]}$ Studies conducted in Turkey indicate high rate of male trauma. Larger social role of male population may be good partial explanation.

Another observation was time of admission to hospital: most were between hours 12:00 pm and 8:00 pm, coinciding with likely hours many family members or caregivers return home from work. No other study was found in the literature with data about admission time, making this valuable preliminary information. Many other factors may also influence time of admission, including climate and environmental conditions, efforts to earn money and get by, and various other elements of daily life; additional studies that examine timing of admission to hospitals are needed.

Literature indicates in majority of geriatric assault cases, perpetrator is child of the victim. ${ }^{[8,9]}$ In our study, in addition to children, spouse or sexual partner was commonly seen. Undoubtedly, in such a complicated and multifaceted matter, more studies are needed. However, we believe that our study is a pioneer and highlights gap in research of this field.

This study made clear that $55.6 \%$ of cases of physical violence had gone to hospital previously as result of violence. This data is important result indicating recurring nature of physical assault. When compared with data in the literature, rate of recurring cases in our study is remarkably higher and evidences necessity to increase social awareness. ${ }^{[23,24]}$ Keeping this truth hidden from view by burying our head in the sand will lead to destructive results. Study conducted by Fisher et al. also draws similar attention to internal family (domestic) violence. ${ }^{[25]}$ Social ignorance and perpetrators often not being appropriately punished in such cases make the problem worse. Our results in this study indicated that geriatric violence at home even includes injuries from firearms, and sending elders back to such an environment without resolution of causes is worrisome.

\section{Conclusion}

It is noteworthy that true number of cases of physical violence against the elderly is almost certainly much greater than the number of reported cases. In cases of abuse and physical violence, the perpetrator is usually a member of the immediate family member or other relative, and majority of recurring cas- es occurred at home, including firearm injuries. Factors influencing reporting include fears of facing violence again, harming relations with family members, and anxiety about being sent to protective government institution and legal procedures. New, broad investigations taking these factors into consideration will contribute to increased social awareness.

Emergency service doctors are of key importance in geriatric violence cases, and they, as well as general practitioners who are familiar their patients and relatives, should keep this problem in mind. Sensitive questioning of the patients could be the first step toward resolution. General Practitioners often get to know their patients well and can evaluate many aspects of a case. Family doctors are well positioned to shed light on violence cases.

In order to keep elders from violent circumstances and to avoid recurrence, shelters for the elderly, similar to those for women, could be established. Furthermore, education of nursing staff and having the means to initiate legal proceedings in such shelters would reduce the number of offenses and contribute to individual safety.

Conflict of interest: None declared.

\section{REFERENCES}

1. Sethi D, Wood S, Mitis F, Bellis M, Penhale B, Marmolejo II, et. al. European report on preventing elder maltreatment. Rome: World Health Organization 2011 Møller \& Kompagni 2011. p. 1-10. Erişim Tarihi: 01.01.2015. http://www.euro.who.int/_data/assets/pdf_ file/0010/144676/e95110.pdf

2. Bilir N. Yaşlılık ve halk sağlığı. İçinde: Gökçe Kutsal Y, Joseph Troisi (Ed): Yaşlılık gerçeği. Ankara: Hacettepe Üniversitesi Hastaneleri Basımevi; 2004. s. 11-29.

3. Acierno R, Hernandez MA, Amstadter AB, Resnick HS, Steve K, Muzzy W, et al. Prevalence and correlates of emotional, physical, sexual, and financial abuse and potential neglect in the United States: the $\mathrm{Na}$ tional Elder Mistreatment Study. Am J Public Health 2010;100:292-7.

4. Dong X, Simon M, Mendes de Leon C, Fulmer T, Beck T, Hebert L, et al. Elder self-neglect and abuse and mortality risk in a community-dwelling population. JAMA 2009;302:517-26. Crossre

5. Perdue PW, Watts DD, Kaufmann CR, Trask AL. Differences in mortality between elderly and younger adult trauma patients: geriatric status increases risk of delayed death. J Trauma 1998;45:805-10. Crossre]

6. National Research Council (US) Panel to Review Risk and Prevalence of Elder Abuse and Neglect; Bonnie RJ, Wallace RB, editors. Elder Mistreatment: Abuse, Neglect, and Exploitation in an Aging America. Washington (DC): National Academies Press (US); 2003. 2, Concepts, Definitions, and Guidelines for Measurement. Erişim tarhi:30.12.2015 http:// www.ncbi.nlm.nih.gov/books/NBK98792/.

7. Phillips LR, Guo G, Kim H. Elder mistreatment in U.S. residential care facilities: the scope of the problem J Elder Abuse Negl 2013;25:19-39.

8. Santos CM, De Marchi RJ, Martins AB, Hugo FN, Padilha DM, Hilgert JB. The prevalence of elder abuse in the Porto Alegre metropolitan area. Braz Oral Res 2013;27:197-202. Crossre

9. Naughton C, Drennan J, Lyons I, Lafferty A, Treacy M, Phelan A, et al. 
Elder abuse and neglect in Ireland: results from a national prevalence survey. Age Ageing 2012;41:98-103. Crossret

10. Caykoylu A, Ibiloglu AO, Taner Y, Potas N, Taner E. The correlation of childhood physical abuse history and later abuse in a group of Turkish population. J Interpers Violence 2011;26:3455-75. Crossret

11. Kaldırım Ü, Tuncer SK, Ardıç S, Tezel O, Eyi YE, Arzıman I, et. al. Analysis of Elderly Patients Presenting to the Emergency Department via Ambulance. Tr J Emerg Med 2013;13:161-5.

12. Akköse Aydin S, Bulut M, Fedakar R, Ozgürer A, Ozdemir F. Trauma in the elderly patients in Bursa. Ulus Travma Acil Cerrahi Derg 2006;12:230-4.

13. Periodic health examination, 1994 update: 4. Secondary prevention of elder abuse and mistreatment. Canadian Task Force on the Periodic Health Examination. CMAJ 1994;151:1413-20.

14. TUİK Ölüm İstatistikleri 2014. Available at: 31.12.2015. http://www. tuik.gov.tr/PreHaberBultenleri.do?id=18623.

15. Arias E, Kochanek KD, Anderson RN. How Does Cause of Death Contribute to the Hispanic Mortality Advantage in the United States? NCHS Data Brief 2015;221:1-8.

16. Committee on Trauma. American College of Surgeons. NTDB Annual Report Chicago: IL 2015. p. 26.

17. Kandiş H, Karakuş A, Katırcı Y, Karapolat S, Kara İH. Geriatric popula- tion and forensic traumas. Turk J Geriatrics 2011;14:193-19.

18. Kara H, Bayir A, Ak A, Akinci M, Tufekci N, Degirmenci S, et al. Trauma in elderly patients evaluated in a hospital emergency department in Konya, Turkey: a retrospective study. Clin Interv Aging 2014;9:17-21.

19. Tanrıkulu CS, Tanrıkulu Y. Geriatrik popülasyonda travma analizi: Kesitsel Çalışma. Yeni Tıp Dergisi 2013;30:100-4.

20. Laumann EO, Leitsch SA, Waite LJ. Elder mistreatment in the United States: prevalence estimates from a nationally representative study. J Gerontol B Psychol Sci Soc Sci 2008;63:248-54

21. Goodmanson NW, Rosengart MR, Barnato AE, Sperry JL, Peitzman $\mathrm{AB}$, Marshall GT. Defining geriatric trauma: when does age make a difference? Surgery 2012;152:668-75. Crossre]

22. Martins R, Neto MJ, Andrade A, Albuquerque C. Abuse and maltreatment in the elderly. Aten Primaria 2014;46 Suppl 5:206-9. Crossre.

23. Fraga S, Costa D, Dias S, Barros H. Does interview setting influence disclosure of violence? A study in elderly. Age Ageing 2012;41:70-5. Crossre

24. Ozsaker E, Demir Korkmaz F, Dolek M. Analyzing individual characteristics and admission causes of elderly patients to emergency departments. Turk J Geriatrics 2011;14:128-34.

25. Fisher BS, Regan SL. The extent and frequency of abuse in the lives of older women and their relationship with health outcomes. Gerontologist 2006;46:200-9. Crossret

\title{
ORIJINAL ÇALIŞMA - ÖZET
}

\section{Yaşlılarda fiziksel şiddet: Acil servise başvuruların analizi}

\section{Dr. Yasemin Kılıç Öztürk, ${ }^{1}$ Dr. Erhan Düzenlii, ${ }^{2}$ Dr. Cem Karaali, ${ }^{3}$ Dr. Faruk Öztürk ${ }^{4}$}

\author{
${ }^{1}$ Tepecik Eğitim ve Araştırma Hastanesi, Aile Hekimliği Kliniği, İzmir \\ ${ }^{2}$ Medicana Konya Hospital, Acil Tıp Kliniği, Konya, Türkiye \\ ${ }^{3}$ Tepecik Eğitim ve Araştırma Hastanesi, Genel Cerrahi Kliniği, İzmir \\ ${ }^{4}$ Menemen Devlet Hastanesi, Acil Servis, İzmir
}

AMAÇ: Fiziksel şiddet kurbanda travma, yaralanma, ağrı ve işlev kaybına yol açmaya yönelik güç uygulama sonucu oluşan ve en sık görülen şiddet türüdür. Türkiye için bu alanda öncü nitelikteki çalışmada fiziksel şiddete uğrayan yaşılıarın sosyodemografik özelliklerin ve şiddet mekanizmasının incelenerek Türk toplumunda yaşlıya yönelik şiddetle savaş için alınabilecek önlemler araştırıldı.

GEREÇ VE YÖNTEM: Geriye dönük çalışmada Ocak 2012 ve Temmuz 2013 tarihleri arasında Şanlıurfa Eğitim ve Araştırma Hastanesi Acil Servisi'ne darp nedeniyle başvuran 54 hastanın veri tabanı ve adli rapor kayıtları değerlendirildi.

BULGULAR: Darp tanılı 54 yaşlı hastanın 50'si (\%92.4) erkekti. Olguların \%55.6'sında $(n=30)$ mükerrer darp tanımlandı. Mükerrer darp ve ateşli silah yaralanma sıklığı evde gerçekleştiği belirtilen olgularda anlamlı yüksek bulundu $(p=0.006, p=0.007)$. Cerrahi gerektiren yaralanma sıklığı evde gerçekleşen darp olgularında daha sık görüldü $(p=0.016)$.

TARTIŞMA: Ateşli silah yaralanması gibi ciddi yaralanmalar ve mükerrer darp olgularının hane içinde gerçekleşmesi darp nedeniyle başvuran yaşılıarın koruma altına alınması gerektiğini göstermektedir.

Anahtar sözcükler: Geriatri; istismar; koruyucu sağlık hizmeti; travma; yaralanma.

Ulus Travma Acil Cerrahi Derg 2017;23(I):56-60 doi: 10.5505/tjtes.2016.90457 